\title{
HVORFOR OPSTOD FOLKEMUSEET? VAR DET BERNHARD OLSENS SKYLD ELLER LA DET I TIDEN?
}

\section{Holger Rasmussen}

Nationalmuseet i 30'erne. Hvilken eventyrverden for en vestsjallandsk bondestudent! Det nye museum var nosten fardigt, og Dansk Folkemuseum rykkede ind fra sit provisoriske ophold på loftsetagen over Kunstindustrimuseet. Egentlig har det altid haft provisoriske opholdssteder, men det fandt jeg forst ud af efterhainden. Dansk Folkemuseum blev min lere- og arbejdsplads gjennem mange år, og det kvitterte jeg for ved at skrive bogen om dets stifter, den mangesidede og mangekyndige Bernhard Olsen.

Bernhard Olsens betydning for Folkemuseet kan kort beskrives således. Georg Karlin, grundlæggeren av Kulturen i Lund, fortalte ved Folkemuseets 25 års jubilæum at han engang fik besøg af en gammel, jysk bondemand, der ikke uden bitterhed omtalte blindheden ved de ældre museer for folkeminderne, der især i Danmark havde haft sine skadelige virkninger. Men så, sagde Karlin, "höjde han stämman og sade på sitt breda bygdemål: "Men da opvakte Gud en mand, der hedder Bernhard Olsen!" Da denne måde at affærdige overskriftens spørgsmål på nok ikke tilfredsstiller, skal jeg forsøge at besvare dem mere detaljeret og i øvrigt henvise til min bog om Bernhard Olsen.

\section{TIDEN OG MANDEN}

To ting må man sætte ind på: Tiden og manden. Jeg tager da året 1879 som skæringspunkt, tiden for Kunst- og Industriudstillingen i København. Hvad var der af kulturhistoriske museer på dette tidspunkt, og hvad dækkede de? Først og fremmest var der Oldnordisk Museum, hvor hovedvægten lå på forhistorien og middelalderen. I 1884 konstaterede Worsaae, at de to foregangsmænd ved museets dannelse havde sat tidsmæssige grænser for dets virke: "Nyrup blev i sit forslag til et Nationalmuseum stående ved Reformationen og Thomsen for Oldsagsmuseets vedkommende ved Suveræni- 
tetens indførelse (1660). Datiden, som i det hele undervurderede de yngste kulturstadiers betydelse, ja som tildels med kunstnerisk ringeagt så ned på rokoko- og empirestilen, havde ikke i tilstrækkelig grad fået øjet åbnet for, at et kulturhistorisk museum ... må til den rette forståelse af nutiden oplyse alle forudgående tidsrum og ikke mindst dem, hvorpå nutidens hele udvikling umiddelbart hviler". Samlingerne på Rosenborg med deres helt specielle karakter, betragtedes som fortsættelsen indtil 1848 med den frie forfatnings indførelse, og højere op i tiden skulle museerne ikke gå.

Et supplement til disse to museer udgjordes af de første provinsmuseer: Ribe (1855), Odense og Århus (1860), Viborg (1861) og Ålborg (1863), hvortil kom Randers (1872) og den første spæde begyndelse til Maribo (1879), der alle må betragtes som mindre udgaver af Oldnordisk museum med hovedvægten lagt på de forhistoriske genstande. Dog kunne "historisk interessante genstande fra senere tider optages i samlingen, såfremt det kunne ske uden tilsidesættelse af dets nærmeste formål", som det fastslås i Viborg museets statutter.

Det er på denne baggrund overlærer Joh. Forchammer i Ålborg i 1866 i Jydske Samlinger skriver om trangen eller dog lysten til overalt i Danmark, "at oprette oldnordiske samlinger, historiske museer eller med hvilke andre navne man har kaldet væsentlig samme ting". Og han finder forklaringen herpå $\mathrm{i}$ "hele den åndelige retning, der går gennem Europa... Frihedens frugter må komme det hele folk så vidt muligt ligeligt til gode". Derfor, siger han, "finder vi den samme stræben $\mathrm{i}$ Norge og Sverige, i Svejts og vistnok mange andre steder i Europa". Det lå altså i tiden. Det vender vi tilbage til, men nu manden.

\section{BERNHARD OLSEN}

Bernhard Olsen (1836 - 1922) var søn af portnerfolket ved Borchs kollegium i St. Kannikestræde. Moderen døde, da han var 6 år gammel og faderen 4 år senere. Vi ved blot, at han gik i Efterslægtselskabets skole, efterfulgt af Teknisk skole for så i 1853 at blive optaget på Kunstakademiet. Som altid, når der er uoplyste perioder i en fremtrædende mands liv, har der været formodninger om en mere passende barnefader for drengen end portneren. Man har også ment, at han var blandt de børn, der flokkedes om "gamle Thomsen", når han fremviste sine samlinger. Harald Engberg hævder i sin bog om Pantomimeteatret, at Bernhard Olsen var et vajsenhusbarn, "et mærkeligt begavet og idérigt Vajsenhusbarn, som senere gav impulsen til "Skansen" i Stockholm (!) og skabte både Folkemuseet og Frilands-museet". Engbergs påstand holder ikke stik. Bernhard Olsens navn findes ikke i Vajsenhusets skoleprotokoller.

Desværre var Bernhard Olsen tilbageholdende med at ytre sig om sit liv. Hans yngre ven og kollega Emil Hannover forsøgte gentagne gange at få ham til at skrive sine erindringer, men forgæves: "Når De har stræbt at drage mig ud af min Uberømthed, må jeg sige Dem, at denne har været min egen forsætlige skyld. Bene vixit, bene latuit har været mit ledemotiv hele mit liv og vil vedblive dermed. Jeg har til eget brug oversat det på Peder Laales dansk, og det er udlagt: Lønligt liv (er) lykkeligt. Det har bevaret mig frisk i 
sind, medens jeg har set mange andre blive inficeret af museumsbacillen og gå til grunde helt eller halvt".

Der er en hel del koketteri i dette credo. For Bernhard Olsen var ingenlunde anonym, tvært imod ofte i søgelyset på grund af sine mange foretagender. Han blev da også hædret. I 1905 fik han to hyldestadresser fra henholdsvis alle betydelige museumskolleger i Stockholm og fra Nordiska Museet. Og 5 år senere en pompøst udstyret adresse fra Folkemuseets bestyrelse. Universitetet i Lund gjorde ham til hædersdoktor i 1918, og derudover var han rigt forsynet med udmærkelsestegn. Da han forlod sin stilling som direktør for Tivoli, fik han tildelt dets guldmedalje. Da udstillingen i 1879 var slut, udnævntes han til ridder af Dannebrog, i 1905 fulgt op af Dannebrogsmændenes hæderstegn, ved museets 25 års jubilæum fortjenstmedaljen i guld og endelig i 1920 "som anerkendelse for sit utrættelige arbejde for folkemuseets udvikling og trivsel" kommandør af Dannebrog. Hvorom ordenshistoriografen 1977 bemærker: "Han er således blevet dekoreret i en grad, man næppe ville gøre det i dag". Trods dette undlod han at levere den beretning til ordenskapitlet, som ellers forudsættes.

Denne tilbageholdenhed er symptomatisk, for han var meget fåmælt om sin egen person. Egentlig har han blot beskrevet sin barndom som et bidrag til Vort Folk $i$ det nittende Aarbundrede (1897) under titlen: "Barndomsminder fra Fyrrerne", der alt overvejende er en kulturhistorisk skildring af hans del af København, men meget lidt om ham selv. Han lægger dog vægt på at understrege forbindelsen til faderens familie på Herlufmagleegnen. Bernhard Olsens faster og hendes mand, der var gårdfæstere

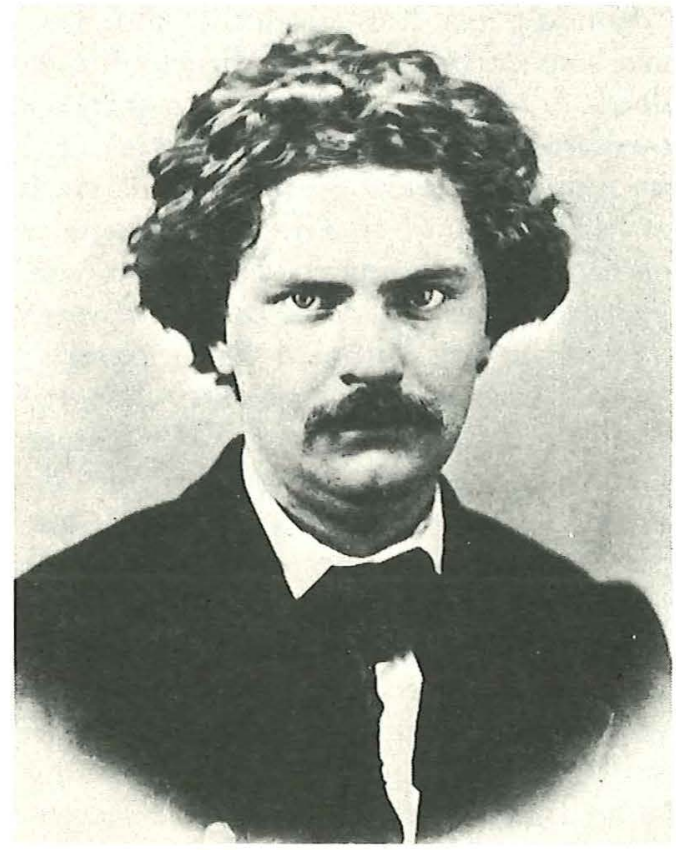

Portratfoto af Bernhard Olsen (1836-1922) efter originalfoto $i$ Teatermuseet, gjengitt $i$ Holger Rasmusssen: Bernhard Olsen. Virke og verker (1979)

i Hjelmsølille, aflagde nu og da portnerfamilien et besøg. Jeg formoder, at bekendtskabet med dem har været med til, at Bernhard Olsen foreslog udstillingen i 1879 udvidet med en afdeling for landbostanden. Hans skildring af dem tyder derpå: "Det var et Par gamle, vindtørre, knoklede Folk af den vidunderlige Race, som efter Udskiftningen byggede vort Land op af dets dybe Forfald i Fællesskabets sidste Tid. De fik i deres unge Dage en ussel Gaard, ravende i Bygfældighed... Jorderne var fulde af Sten og Pytter med staaende Vand, overgroet med Ukrudt og Krat, men de bandt an med denne stenbundne og vandsyge Jord, og de fik Bugt med den, og som gamle Folk sad de godt i det". 
32 Samtidig med Kunstakademiet kom han i lære som xylograf i træskærerfirmaet Kittendorff \& Aagaard, hvor hans tegnetalent medførte, at han relativt hurtigt blev taget fra skæring af trykklodser og i stedet "sat til at tegne senere til at skrive og oversætte til de forskellige illustrerede Tidsskrifter, som Firmaet udgav". Et af dem var Illustreret Tidende, hvortil Bernhard Olsen allerede i første årgang tegnede og beskrev de nyligt fremdragne kongedragter på Rosenborg. Det blev til en lang række arbejder for tidsskriftet i de følgende år, både selvvalgte som dragter, folkelivsbilleder og prospekter og illustrationer til aktuelle begivenheder.

Som medlem af Kunstnerforeningen af 18. November ledede han udsmykningen ved nogle af dens karnevaller og andre festligheder. Ifølge traditionen var det disse arrangementer, der anbragte ham som direktør for Tivoli (1868 - 86) i konkurrence med overkrigskommissær HøeghGuldberg og skuespiller Otto Zink. Han har selv vurderet disse år som meget gavnlige (ifølge Hannover $\mathrm{i}$ "et stykke selvbiografi", som det ikke har været muligt at opspore), fordi de gav anledning til rejser for Tivolis vedkommende årligt til forskellige steder i Europa for at hente ideer hjem: "Jeg har lært meget dér; jeg kom ind i mangfoldige fag, hvortil kundskabet har gavnet mig senere. Da forholdene på etablissementet opfordrede dertil, blev jeg sat ind i megen praktisk virksomhed, lærte bygnings- og belysningsvæsen, havekunst o.s.v., fik Europa at se ved årlige rejser og kom til de store udstillinger".

Bernhard Olsen hentede erfaringer mange steder $\mathrm{i}$ forskellige rollefag. Som løjtnant i 1864 sendte han tegninger og beretninger fra feltlivet til Illustreret Tidende. Som kostumier ved det Konge- lige Teater og andre københavnske scener havde han opdrag sideløbende med sin virksomhed ved Tivoli og han nøjedes ikke med kostumetegninger til de enkelte forestillinger, men fremsatte sine synspunkter på hele udformningen af stykkerne $i$ et par artikler fra 1880 i det nystartede Ugeskrift for Theater og Musik med det kendskab til fransk teater han havde erhvervet ved et studieophold ved Théatre français i 1875. Ved Holberg-jubilæet i 1884 ønskede chefen for det Kgl. Teater at "de Holbergske Skuespil ønskes givne i nyt og fuldstændigt correct Udstyr saavel hvad Costumer som Decorationer, Meubler m.m. angaar". Bernhard Olsen fik ansvaret for "Den politiske Kandestøber". På et senere tidspunkt gjorde han over for Dansk Folkemuseums forretningsudvalg rede for, at " $i$ Erkendelse af at Teatret intet autentisk ejede fra Tiden 1720-30, efter hvis Mode Holbergske Figurer bør klædes, blev jeg ved Holberg-Jubilæet, skønt for længst fjernet fra min Plads ved Teatret, af dettes Styrelse anmodet om at ordne Kostumeringen af et af de opførte Stykker. Det er det eneste Forsog som gjordes paa at skaffe Holberg en korrekt Udstyrelse, men ved det er det bleven". Man mærker sig den sidste sætning. Bernhard Olsen vidste nok, hvad han var værd. Og det vidste andre også. Skuespillere, der søgte hans råd, fik detaljerede anvisninger. Det fremgår bl.a. af et brev til Olaf Poulsen (april 1880) om dragter til Holbergs skuespil. Og ligeledes til Hans Tegner ved illustreringen af Ernst Bojesens jubeludgave, hvor Bernhard Olsen ikke blot var garant for dragternes nøjagtighed, men hvor han også forsynede kunstneren med minutiøse beskrivelser og kommentarer og henvisninger til værker og samlinger. 


\section{DE STORE UDSTILLINGER}

Lad os vende tilbage til tiden med Forchammers konstatering af oprettelsen af museer overalt i Europa i 1860'erne. 60'erne og 70'erne var også de store udstillingers tid. Man ønskede at demonstrere, hvor herligt vidt man havde bragt det med de tekniske landvindinger. Det var så afgjort formålet med udstillingen i London 1851 i det til lejligheden opførte Krystalpalads. Følgende verdensudstillinger havde vel samme sigte, men gav desuden plads for kulturhistorisk (etnologisk) materiale. Skelsættende er udstillingen i Paris 1867, hvor den franske udstillings komité havde lagt specielt vægt på costumes populaires des diverses contrées, hvor Frankrig selv viste en serie, indsendt fra landets forskellige departementer. Størst opmærksomhed vakte dog den svensk-norske afdeling, der bestod af $\mathrm{i}$ alt 15 dragtdukker med svenske, norske og samiske dragter, udstillet i nicher. Dragterne var på realistisk udformede dragtdukker og vakte vældig interesse. En dansk journalist beskrev dem således: "Udførelsen er så illusorisk, at mange besøgende anså disse figurer for levende; ikke blot er dragterne usædvanlig smukke, men de bæres af virkelige folketyper, hvis gruppering, ansigter og hænder snarere gør det hele til en samling genreskulpturer end til udklædte dukker".

Svenske folkedragter mere og mere bevidst udformet i genremæssige opstillinger vistes i Wien 1873 og i Philiadelphia 1876. Det skal bemærkes, at ingen af disse var Hazelius ansvarlig for, og ligeledes, at Bernhard Olsen ikke ses at have kendt til disse udstillinger.

Da en ny verdensudstilling skulle finde sted i Paris i 1878, var det imidlertid
Artur Hazelius, der stod for den svenske afdeling, som han udformede i fire tableauer og nogle fritstående dragtdukker. Tableauerne bestod af to eksteriører med malede panoramaer som baggrund, nemlig en lappelejr med rensdyrforspand og en gruppe bønderfolk fra Dalsland. Desuden to interiører det ene af en hallandsk bondestue med mand, kone og kat og det andet det rørende "Lillans sista bädd", som Hazelius havde udformet efter Amalia Lindegrens maleri i sentimental Düsseldorfstil. Tableauerne var afskærmede på de tre sider og åbne ud mod publikum.

Sverige var ikke alene om at udstille dragter i fortællende opstillinger. Nederlandene mødte op med deres most picturesque national custumes, som opstilledes i grupper "efter svensk maner" som en markedsscene, et ægtepar fra øen Marken, et ung par på isen og fiskere fra Scheveningen. I en original stue fra Hindeloopen, der i 1877 havde været vist på en historisk udstilling i Friesland, vistes en gruppe i færd med forberedelserne til en barnedåb.

Det er denne udstilling i Paris, der må tillægges afgørende betydning for, at Dansk Folkemuseum blev til og at det skete ved Bernhard Olsen. Det kan sammenfattes i det gamle eventyr om åmanden, der kræver sit offer ved at omgøre hans krav: Tiden er kommen, men manden er ikke kommen til: Tiden er kommen og manden er også kommen. Her forenes de to forudsætninger for museets tilblivelse.

Bernhard Olsen var i Paris for at finde nyheder til sit Tivoli. Han skrev hjem til Illustreret Tidende om eksotiske befordringsmidler i den zoologiske acclimationshave i Boulogneskoven, om den tunesiske cafe på verdensudstillingen og om de gamle træer på Robinson, et yndet udflugtsmål for pari- 
34 serne og forsynede artiklerne med tegninger. Men omtalen af udstillingen selv havde Illustreret Tidende givet til en anden af sine medarbejdere. Bernhard Olsen havde imidlertid nøje studeret udstillingen og drøftet den med Hazelius på stedet (han nævner det $\mathrm{i}$ et brev til Hazelius af 17/1 1879: "da vi talte sammen så ofte"). På et senere tidspunkt (en redegørelse for Folkemuseet i Illustre-ret Tidende, 1885) gav han følgende vurdering af den svenske dragtudstilling: "Man fornemmede, at her var skabt noget helt nyt, et gennembrud for en ny museumsidé vedr. befolkningsgrupper, hvis liv og færden hidtil var forblevet uænset af den traditionelle og officielle opfattelse..."

Ydede han således Hazelius skyldig respekt, var han dog mere optaget af den nederlandske afdeling: "Hollænderne havde enten af egen opfindelse eller af Hazelius' indflydelse skabt deres eget lille folkemuseum, der ganske afveg fra den svenske udstilling. Medens denne viste interiørerne i små rum omgivet af tre vægge, fuldstændig som i voksfigurkabinetter, der på mange måder har været forbilledet for Hazelius, så havde Hollænderne rejst en hel stue, som man kunne gå ind i. Hvert stykke stammede fra gamle huse og fandtes på sin rette plads. Virkningen var - i modsætning til den svenske måde - gribende, og i samme øjeblik, hvor jeg trådte ind i denne gamle stue, der var som en anden verden, fjern i tid og rum fra den myldrende, moderne nutidsudstilling, blev det mig klart, at således skulle et folkemuseum indrettes".

\section{FOLKEMUSEET TAGER FORM}

Muligheden for at realisere denne idé, eller ialtfald at gøre begyndelsen hertil kom hurtigt efter besøget i Paris. I Køben-havn arbejdede man med en udstilling af "ældre og nyere Kunst- og Industrigen-stande", som det hed i udstillingskomiteens henvendelse til offentligheden. Man havde taget model efter tilsvarende udstillinger i udlandet ved at ville præsentere "en Udstilling af kunstneriske og industrielle Frembringelser fra Ind- og Udlandet, fortrinsvis dog af sådanne Genstande fra de tre sidste Århundreder, som er blevne til eller har været i Brug i de gammeldanske og de i øvrigt til Danmark i det nævnte Tidsrum endnu hørende Lande... alt ordnet chronologisk for navnlig at bidrage til at give et, vore kulturhistoriske Museer supplerende fyldigt og levende Billede især fra Reformationstiden til vore Dage foregående kunstneriske og industrielle Udvikling i vort Fædreland". Man tilstræbte således en historisk udstilling, der skulle tjene til inspiration for nutidig skaben, og i hvert fald et af komitemedlemmerne, rustmester Georg Christensen, der var formand for Industriforeningen, håbede på, at resultatet kunne blive et kunstindustrielt museum.

$\mathrm{Nu}$ blev det i stedet et folkemuseum, for ved komiteens andet møde 15/1 1879 kunne dens formand arkæologen J.J.A. Worsaae oplyse, at "løjtnant Bernhard Olsen, der meget har beskæftiget sig med alt, hvad der vedrører ældre moder i de forskellige dragter, havde lovet at ville støtte komitéen i denne henseende, men tillige ment bedst at kunne fremme sagen, når han kunne påberåbe sig en udtrykkelig bemyndigelse".

I bemyndigelsen var ikke nærmere angivet, hvad han skulle tage sig af ud over dragterne, men sine planer røbede han i det tidligere omtalte brev af 17/1 1879 til Hazelius, altså skrevet umiddelbart efter komiteens tilsagn. I brevet hedder det: "Senere (efter deres samtaler i Paris) har jeg 


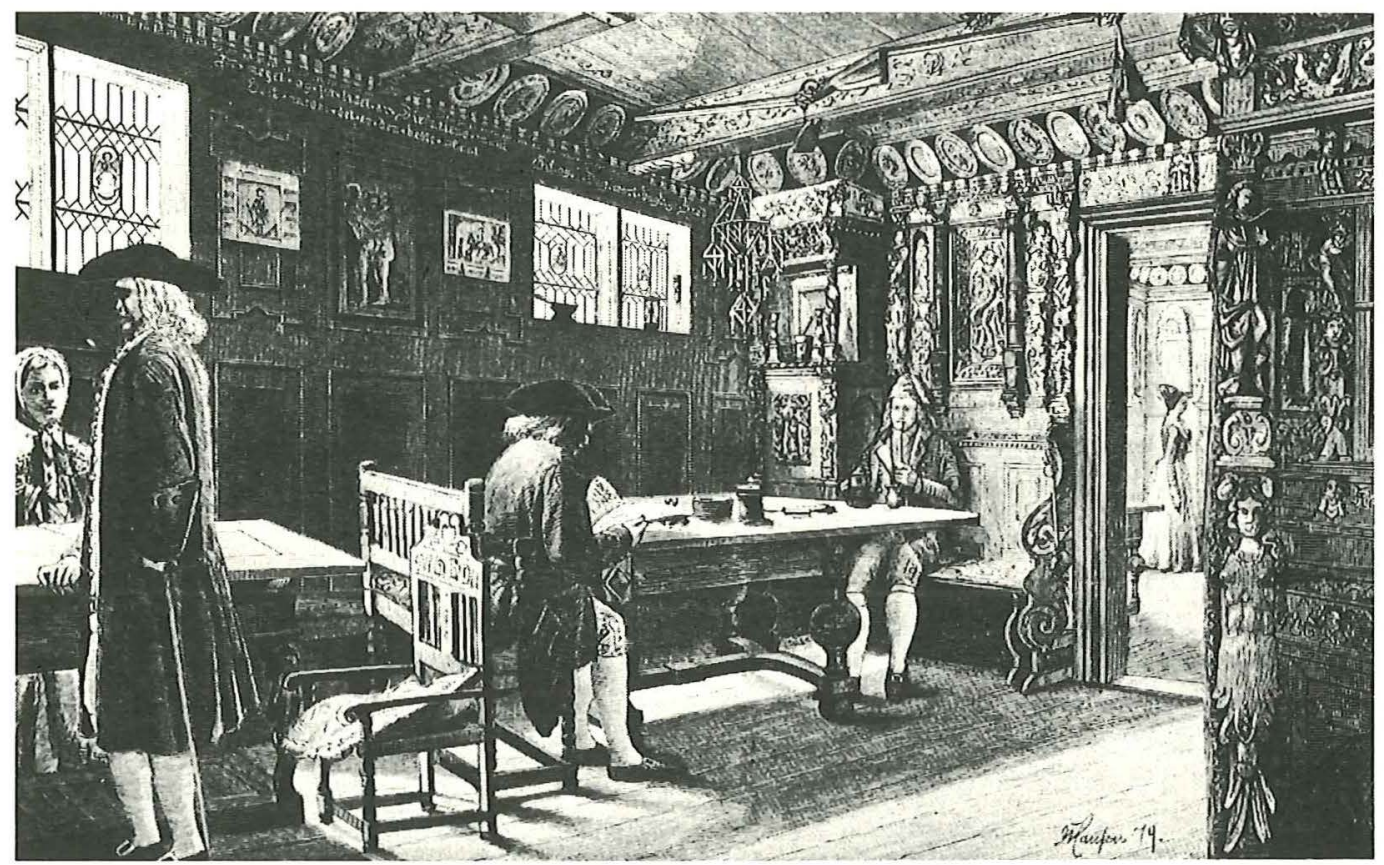

Hedebostuen på den kunstindustrielle udstilling i Kobenhavn 1879. Tegning afJ. T. Hansen. Illustreret Tidende 7. september 1979.

gjort alt, hvad der stod i min magt ved at agitere for et nationalt museum i Danmark, og jeg har begyndt at vække interesse for sagen, endog $i$ en sådan grad, at jeg har fået det hverv at samle og ordne afdelingen for kostumer og husflid i den retrospektive kunstindustrielle udstilling, som skal åbnes i København i juni. - Som De vil se, er det allerede et betydeligt skridt fremad, at jeg har faet den historisk-etnografiske videnskab optaget $i$ udstillingsprogrammet, bvilket ikke var påtenkt oprindeligt, og der skal, det lover jeg, blive gjort et energisk forsog på at samle alt, hvad vi har tilovers af gamle folkeminder her $i$ Danmark. Har man det forst samlet, er vejen til et museum ikke lang, og det skal nok kom$m e "$.

Men foreløbig havde han nok at gøre med at låne ting ind, for såvel afdelingen for landbostanden, som han kaldte sin del af udstillingen, som det kommende museum begyndte på bar bund. Og der var kun nogle få måneder til indsamling, registrering, eventuelt helt nødvendig konservering og opstilling. Når det lykkedes, må det først og fremmest tilskrives Bernhard Olsens utrolige arbejdsformån samt en god skoling ved arrangementerne i Kunstnerforeningen og $\mathrm{i}$ Tivoli. Han har $\mathrm{i}$ et brev til redaktør Vilh. Topsøe (9/6 1880) nogle bemærkninger om sit arbejde hermed: Resultatet af arbejdet var, skriver han, "at jeg i april havde skaffet de fire stuer (hvoraf amagerstuen, hedebostuen og melsalen fra Bornholm opstilledes), stof til 70 figurer med nationaldragter, den svenske afdeling 
36 og betydelige dele af komitéens udstilling (bl.a. det Kgl. teaters store bidrag af dragter). Der mødte over 1.000 udstillere og et kaos af omtrent 10.000 udstillingsgenstande, et urede af gamle klude og rustent kram, om hvis udseende før ordning loppetorvet næppe giver en anelse. Der var væggetøj i alle paneler og møbler og et støv og en lugt i de hundred år gamle bondeklæder, der var værre end cayenne... Hver stump har jeg selv sat op med egne hænder, nummereret og beskrevet i katalog uden at have den ringeste medhjælp af bureaukomité eller lignende indretninger".

Hans afdeling for landbostanden adskilte sig markant fra den kronologisk ordnede af enkeltgenstande som et samspil af genstande i flere niveauer, som det kan ses af Budtz Müllers store fotografier. Nyt og overraskende for et hjemligt publikum var de realistiske dragtfigurer opstillet i fortællende grupper, men uden det drama, som Hazelius ofte tilstræbte. Nyt var også de komplet udstyrede bondestuer, som man kunne gå ind i. Men ikke blot udstillingsformen var ny og overraskende. Det gjaldt også forklaringen til de udstillede ting. Af udstillingskatalogens 272 sider udgør den første del, hvor de enkelte genstande opregnes ganske kort konge for konge fra Christian I. til Frederik VII, 198 sider, resten beskriver bondestand og håndværk, men det er denne del, der ved sin disposition og udformning har nyhedens interesse, for her fremhæres de udstillede genstande ved i stort omfang at være udvidet med kulturhistoriske kommentarer, der placerer og forklarer dem.

Selv i den travle indsamlingsperiode havde Bernhard Olsen afset tid til at publicere et par kronikker i National-tidende (Om Husflidskunster i Hedebo-egnen og Mode og
Nationaldragt), og det fulgte han i udstillingstiden op med en række artikler i Illustreret Tidende om dragter, bondestuer, bylav, husgeråd, drikkeskik og drikkekar, hvor han fyldigere end i katalogen og med illustrationer kunne slå til lyd for sin idé om at holde så meget som muligt af det indsamlede sammen, når udstillingen var til ende. Det var det kommende museum, han argumenterede for.

Når Folkemuseet og andre kulturhistoriske museer af samme art opstår ved denne tid - man behøver blot at nævne det samtidige museum i Lund, "Kulturen" og de to norske museer Norsk Folkemuseum og de Sandvigske samlinger i Lillehammer - så var jordbunden gødet godt gennem fokelivsskildringer i litteratur og malerkunst. Det lå altså $\mathrm{i}$ tiden. Men museet måtte vente på sin mand. Inspirationen, påvirkningen, kan også påvises. Hazelius spillede en rolle ved tilblivelsen af alle de nævnte museer, uden at de blev kopier af hans museum, hans ideer. I mange henseender gik de deres egne veje, også i opposition til Hazelius.

Når Hazelius kaldte sit museum Nordiska Museet, er der en reminiscens af svenske stormagtsdrømme i det, som også fik udtryk i de mængder af norske genstande, som i vognlæs kørtes over grænsen til Stockholm. De norske museer kan betragtes som en reaktion på denne museumspolitik. Også danske genstande søgte Hazelius at sikre sig, men i langt beskednere omfang. Når Bernhard Olsen fik så stor fremgang i indsamlingen af genstande fra de skånske landskaber, skete det delvis som en reaktion mod Nordiska museet. Karakteristisk er således det tilbud, som Karlin og Martin Weibull kom med, for at værge landsdelen, "de gammeldanske provinser mod Hazelius' febrilske indkøb". 


\section{DET NATIONALE MUSEUM}

Bernhard Olsens indsats er ikke en reaktion på Hazelius' virke. Hvad var da hans tanker om Dansk Folkemuseum? Han havde slået til lyd for et nationalt museum, men for ham var et større nationalt begreb aldeles afgørende. I 1906 forklarede han det for Emil Hannover: "Det er mig om at gøre, at få præciseret, hvad der har været min ledende tanke med museerne i by og ved Folevad fra den første stund, jeg fik deres dannelse i hånd. Oldnordisk Museum havde efter Thomsens tid betragtet de tabte lande østensunds som absolut udland. Efter Slesvigs tab fik det samme skæbne og gled såvelsom de skånske lande helt ud af museets område og arbejde (at dette delvis er anderledes nu, skyldes mit initiativ)". Og siger han, da man i undervisningen har fulgt museets eksempel, "er resultatet blevet sørgeligt. Vi har gjort os skyldige $\mathrm{i}$ en slap opgiven af det nationale fællesskab".

To mål havde Bernhard Olsen sat for sin gerning. "Min hensigt med museerne var at råde bod på det forsømte og forvanskede, og i valget af bygningerne ved Lyngby har jeg søgt ikke alene af finde tråden i husets udvikling fra arne til muret skorsten, men de er udtagne fra de tabte lande ikke alene, fordi de primitiveste typer fandtes der, men fordi ungdommen her skal beleres om alt det, der en gang har hort til Danmark, festne mindet om det tabte og bane vejen for den andelige samling af det spredte, der er den eneste form for en generobring, som jeg kan ojne".

Var Bernhard Olsen skyldig? Ja, ellers burde han have holdt fingrene fra udstillingen i 1879 og ikke have brugt den som udgangspunkt for dannelse af et museum, som han i første fase kaldte Samlingen af den danske Bondestands Fortidsminder og snart derefter med Worsaaes velsignelse for Dansk Folkemuseum $i$ København. Hans museumstanker fik bred opbakning blandt de folk, der havde sendt ting til udstillingen. Bonden Hans Chr. Hansen i Ejstrup ved Løgstør skrev til ham i 1881: "Det har glædet mig at se i aviserne, at der nu er gjort skridt til at få et folkemuseum oprettet i København i lighed med, hvad de allerede længe har havt i Stockholm... Det er jo særlig bondestanden, De har henvendt Dem til. Det har glædet mig, fordi jeg troer, at det er på høje tid..."

Med ændringen af museets navn ønskede Bernhard Olsen at præcisere, at det han tilstræbte, var et folkeligt museum - i et brev til arkitekt F. Meldahl i 1879 havde han kaldt det et dansk ethnografisk museum - for borgere- og bondestand for tiden fra midten af det 17. til midten af det 19 . århundrede som en fortsættelse og fuldstændiggørelse af de eksisterende historiske samlinger. "Medens disse væsentlig optage Gjenstande af virkelig historisk eller kunstnerisk Værd, vil vort Museum blive rent kulturhistorisk og give et samlet malerisk Billede af vore folkelige og provinsielle Ejendommeligheder" (marts 1881). Med det ændrede navn fulgte således et bredere sigte.

Hovedparten af danske museer ville aldrig være blevet til det, de er, hvis ikke mennesker af en særegen støbning havde givet tid og kræfter - ofte ud over al rimelighed - til at føre sagen igennem. Et sådant menneske var Bernhard Olsen. Hans eksempel og det museum, han skabte, fik stor indflydelse på lokalmuseerne. For et enkelt af dem, museet i Maribo, fik det afgørende betydning.

En af de ivrigste medhjælpere ved indsamlingen til udstillingen i 1879 var hus- 
38 mand og musiker J. Olsen i Bakkebølle. Han havde tidligere været en virksom lokal medarbejder for Oldnordisk museum efter direkte kontakt med Worsaae. Nu fortsatte han efter Folkemuseets dannelse som en interesseret medarbejder for dette. Da han i 1890 blev kustode ved museet i Maribo, var hans første opgave at flytte museets samlinger til den nye museumsbygning. Det betød en total gennemgang af genstandene med mærkning og sortering, og det er værd at mærke sig, at han til ordningen af de historiske samlinger fulgte det system med opdeling i saglige grupper, som Bernhard Olsen havde făet sat i værk fra $1892 \mathrm{og}$ făet trykt samme år i Folkemuseets katalog over dets samlinger.

\section{SUMMARY}

Why did the Danish Folk Museum come into being?

Holger Rasmussen has (1979) written a standard biography on Bernhard Olsen (1836-1922), who founded the museum in 1879, opened it in 1885 and in 1901 established the open-air museum, Frilandsmuseet, at Lyngby as a part of the museum. In his paper he asks whether the museum was the product of an age or the creation of a specific personality - Bernhard Olsen.

The age saw the birth of many museums in Denmark, most of them collecting and exhibiting prehistoric objects and modelled on C J Thomsens museum in Copenhagen. But in Sweden Artur Hazelius and Georg Karlin had started another type of museum projects inspired by the folk-concept. The World Exhibitions favoured romantic representations of a picturesque folk-culture, in their turn inspired by the popular genre-painting and the nostalgic and sentimental novels of the day.

Bernhard Olsen had very wide interests, was trained as an artist and worked as costume designer for the theatre as well as entertainer and writer for the press. He became the director of the well-known Copenhagen
Tivoli. In 1878 he had visited and studied the World Exhibition in Paris, where he had met Artur Hazelius. He returned home very impressed with what he had seen, more so with the manner in which the Dutch had presented their folk culture with room interiors, which the visitor could enter, than with the picturelike exhibitions of Hazelius. When given the responsibility in 1879 to arrange a section of an Exhibition on Arts, Crafts and Industry in Copenhagen, which should present folk costumes and traditional crafts, Olsen set out with the purpose to start the collecting for a new museum. He chose to arrange the material in three interiors with 70 mannekins in costumes - much in the Dutch fashion he had seen in Paris.

His exhibition was very successful and became the starting-point for his career as creator of both Dansk Folkemuseum and Frilandsmuseet. Thus, the paper concludes, the creation of the museum was dependent both of the spirit of an age for its creation and reception - and of the strong purpose in a gifted personality.

Holger Rasmussen er cand. mag i historie, dansk og tysk. Assistent ved Dansk Folkemuseum fra 1942, inspektor fra 1946 og overinspektor samme sted fra 1959. Dr. phil. på afhandling om Limfjordsfiskeriet 1968.

Adr.: Fuglsangsvej 30, DK-2830 Virum

\section{LITTERATUR}

Holger Rasmussen: Dansk Museumshistorie. De kulturbistoriske museer. København 1979.

- Bernhard Olsen. Virke og verker. København 1979.

- Kustode J. Olsen, Maribo. Musiker-oldsagssamlermuseumsmand. Lolland-Falsters Stiftsmuseums årsskrift 1977, 12-41. 